\title{
PARAGLACIAL MODIFICATIONS OF GLACIAL SEDIMENTS OVER MILLENNIAL TO DECADAL TIME-SCALES IN THE HIGH ARCTIC (BILLEFJORDEN, CENTRAL SPITSBERGEN, SVALBARD)
}

\author{
GRZEGoRZ RACHLEWICZ \\ Adam Mickiewicz University, Institute of Geoecology and Geoinformation, Poznań, Poland
}

Manuscript received July 15, 2010

Revised version August 28, 2010

Rachlewicz G., 2010. Paraglacial modifications of glacial sediments over millennial to decadal time-scales in the high Arctic (Billefjorden, central Spitsbergen, Svalbard). Quaestiones Geographicae 29(3), Poznań 2010, pp Poznań 2010 pp. 59-67, 7 Figs. ISBN 978-83-62662-04-3. ISSN 0137-477X. DOI: 10.2478/v10117-010-0023-4.

ABSTRACT. The paper discuss the morphologic expression and sedimentological record left after the operation of glacial episodes in the area of Billefjorden, central Spitsbergen, in the period of Late Pleistocene ice-sheet development and in the last advance of glaciers in the Little Ice Age (LIA) around the beginning of the $20^{\text {th }}$ century. No evidence is found for other Holocene glacier advances. Paraglacial activity during several millennia erased the surface expression of Pleistocene glacial deposits, leaving a widespread set of reworked material that adopts features of slope, fluvial, aeolian or littoral environments. Glacial features generated during the past century, and still forming in front of retreating glaciers, undergo intense paraglacial modifications limited to the maximum depth of permafrost thaw during the summer. They deliver vast amounts of erosion-susceptible material from mass movements on buried ice fragments, through the glaciofluvial system to aeolian and littoral activity.

KEYWORDS: glacial geomorphology, Quaternary glaciations, sediment characteristics, paraglacial modifications, Spitsbergen

Grzegorz Rachlewicz Institute of Geoecology and Geoinformation, Adam Mickiewicz University, Dziegielowa 27, 61-680 Poznań, e-mail: grzera@amu.edu.pl

\section{Introduction}

Nowadays a world-wide recession of glaciers is observed (e.g. Oerlemans 2005; Dyurgerov \& McCabe 2006), uncovering from the ice extensive areas of fresh and unconsolidated material, transported by glaciers often somewhat like with a conveyer belt (Armstrong et al. 2002), and easy available for further transformations. Glacial landscape alterations are most intensive in the marginal, ice-contact environment, extending to the proglacial zone of the main influence of glacier melt-water and the proglacial area, due to the intensity of ice decay (Evenson \& Clinch 1987; Rachlewicz 2003a). The paraglacial concept introduced in the early 70s, in relation to non-glacial processes directly conditioned by glaciation (Ryder 1971, Church \& Ryder 1972), was extended in 


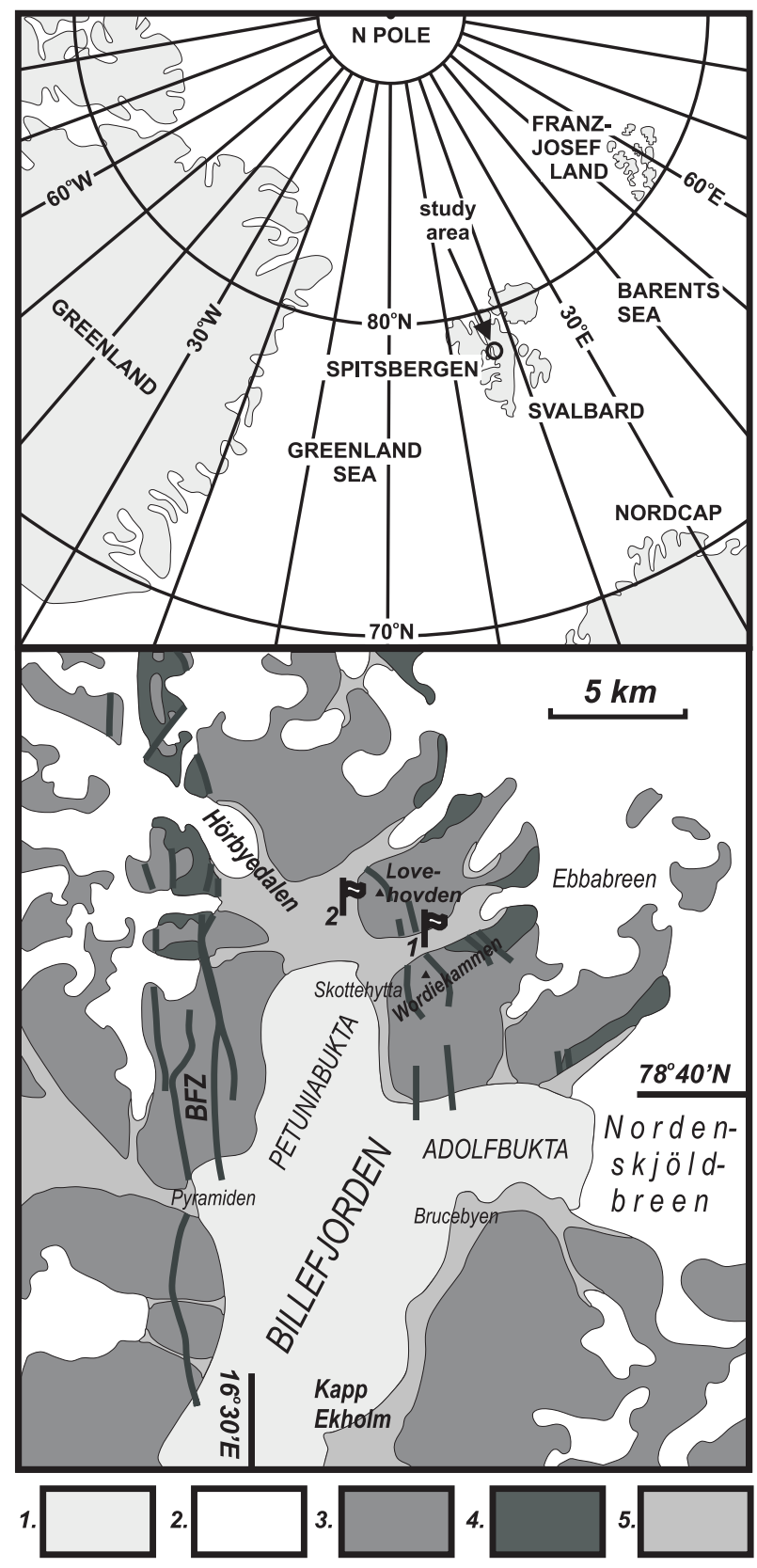

Fig. 1. Location of the study area.

1. fiord; 2 . glaciers; 3 . sedimentary rocks; 4 . metamorphic rocks; 5 Quaternary covers. Solid lines represent main faults; BFZ - Billefjorden Fault Zone. Flags identify location of sites in Ebbadalen (1) and at the foot of Løvehovden (2).

recent decades to cover landforms, land systems and landscapes that are directly conditioned by glaciation and deglaciation, where sediments are non-glacially reworked to attain a non-glacial state (Ballantyne 2002a, b). The latter was challenged by Slaymaker (2009) as too broad and unclear. The present paper aims to document examples of supposed Holocene and morphologically well-marked recent glacial forms in the surround- ings of Billefjorden, central Spitsbergen, adjusted to contemporary environmental conditions in terms of high Arctic morpho-lithogenesis. It also considers the intensity of post-glacial landscape changes, during several thousands of years and in the past few decades, due to non-glacially conditioned processes, as long as they reflect some features of primary depositional environment.

The study area in Billefjorden, in the innerfiord part of Spitsbergen, the largest island of the Svalbard archipelago (Fig. 1), has been well represented by studies of Pleistocene glacial history on the base of the classic Kapp Ekholm key stratigraphic sections, first described by Lavrushin (1969), studied e.g. by Boulton (1979), revised by Mangerud \& Svendsen (1992) and regionally summarized by Mangerud et al. (1998), and in the northern part of the fiord, in the Hörbyedalen section (Karczewski \& Rygielski 1989). Both show no occurrence of larger advances of glaciers later than $10 \mathrm{ka}$ BP. Several papers however document remnants of marginal zones of Holocene glaciers at $78.7^{\circ} \mathrm{N}$ in Petuniabukta (e.g. Kłysz et al. 1988, 1989; Stankowski et al. 1989), the northern arm of Billefjorden, where large Ushaped valleys descend from the margin of an extensively glaciated interior, covered with the ice plateau Lomonosovfonna, elevated above 1000 $\mathrm{m}$ a.s.l. These reports are contrary to others that suppose higher elevation of equilibrium line altitudes of some Svalbard glaciers and their reduction in area (or even total disappearance) during the Holocene, up to the $16^{\text {th }}-19^{\text {th }}$ century Little Ice Age (LIA) advances (Svendsen \& Mangerud 1992; Snyder et al. 2000).

\section{Methods}

Two sites on the east side of Petuniabukta have been re-investigated and described in terms of their morphological and geological setting. In samples collected from outcrops grain size distribution was studied using a combined sievingsedimentary method to compute basic statistics (Folk \& Ward 1957) with the GRADISTAT computer application (Blott 2000). Separated gravel grains, more than 200 in each sample, were examined using the Powers (1953) scale (average roundness index $R_{i}$ was given) and for petro- 
graphic composition, distinguishing between sedimentary and crystalline particles (petrographic index $P_{i}$ is the number of sedimentary rock particles divided by the number of particles in the sample). In addition shell fragments from each sample were collected and an attempt to determine mollusc species was undertaken.

\section{Traces of pre-LIA glacier advances}

Part of the highest marine terrace in the bottom of Ebba valley and in Ebba river gap (No. 1 on fig. 1, fig. 2) was classified by Kłysz et al. $(1988,1989)$ as the remnant of an Early Holocene transgression named Ebbadalen Stage, delimited by erratics at the place of ice-cliff stagnation, followed by the deposition of marine sediments. In their opinion it is associated with glacier undercuts and moraines on the southern valley slopes (Wordiekammen massif). The surface is elevated up to $40-45 \mathrm{~m}$ a.s.l, lowering towards the bottom of the valley (to 10-15 m a.s.l.) with terrace steps. It is covered with continuous sandy-gravel sediments layer of marine origin. On the surface several erratic boulders occur, both metamorphic and sedimentary: the largest reach $2.0 \mathrm{~m}$ in diameter and were found at all terrace levels, down to the present sea coast.

The pit excavated in the upper part of the terrace (about $30 \mathrm{~m}$ a.s.l. - Fig. $2 \mathrm{~b}$ ), under a $0.04 \mathrm{~m}$ thick layer of aeolian deposits, reveal a dual setting. The upper $0.3 \mathrm{~m}$ consist of loose gravellysandy-clayey mixtite with stones up to $0.2 \mathrm{~m}$ in diameter and shell fragments. Beneath, a typical glacial diamicton was found, heavily packed, with compaction cleavage and crushed shell fragments. The upper layer characteristically differs from other sediments described below, because of a higher roundness index $\left(\mathrm{R}_{\mathrm{i}}=5.5\right)$ and more homogenous petrographic composition, with distinct predominance of sedimentary rocks $\left(\mathrm{P}_{i}=\right.$ $0.88)$. Underlying sediments contain over $50 \%$ of fine fractions, gravel roundness is less noticeable $\left(\mathrm{R}_{\mathrm{i}}=3.5\right)$ and the amount of metamorphic rocks fragments is higher $\left(\mathrm{P}_{\mathrm{i}}=0.71\right)$.

The section in the southern bank (Fig. 2c) of the ravine segment of the Ebba river, is located $10 \mathrm{~m}$ a.s.l. at the edge of a surface sloping NE towards the valley axis. The $2.0 \mathrm{~m}$ deep geological profile

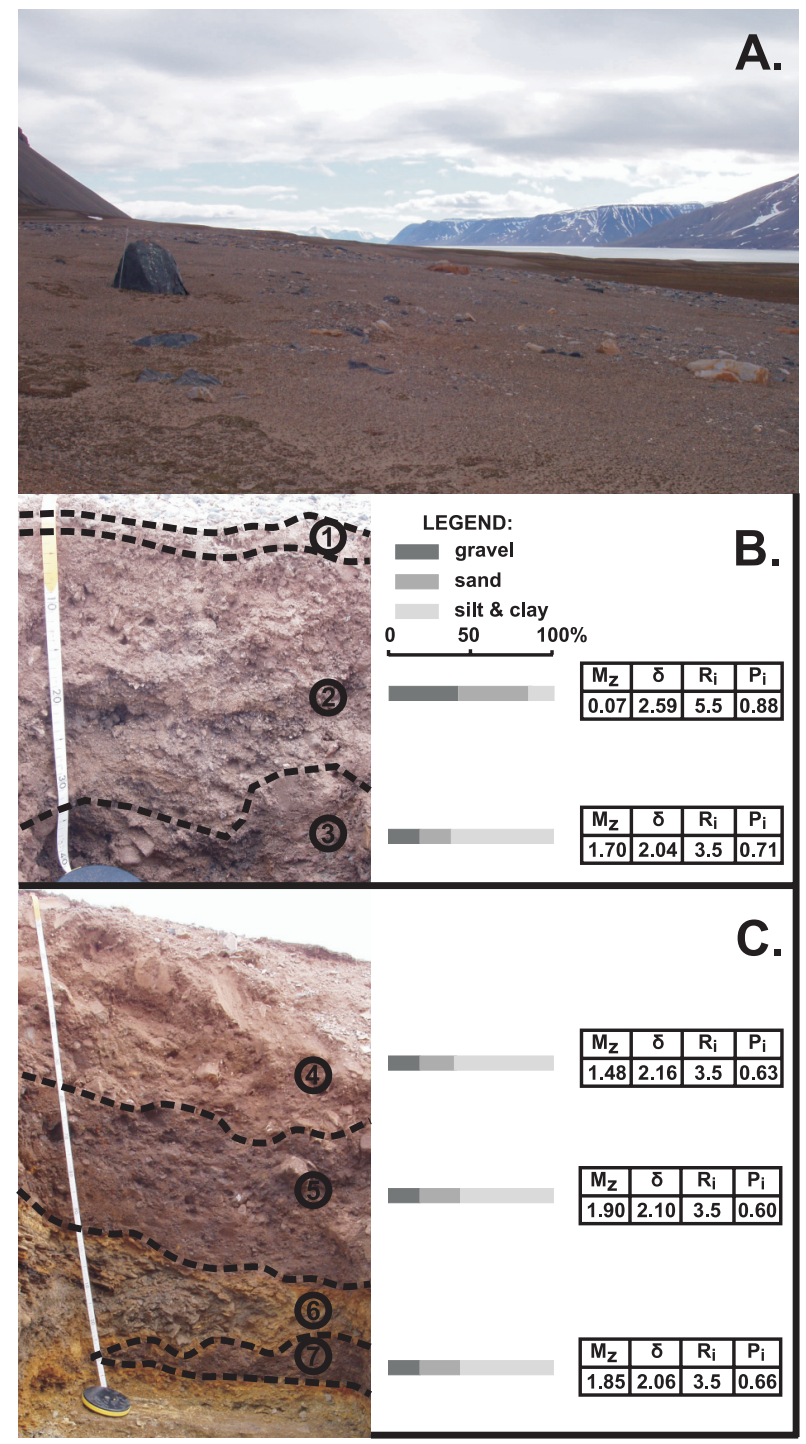

Fig. 2. Study sites in Ebbadalen: A. General view of the

highest terrace in the axial part of the valley with the concentration of erratic blocks on the surface; B. Sediment profile in the upper part of the terrace; C. Sediment profile in the Ebba River ravine segment.

Gray-scale bars indicate the simplified grain size composition of sediment samples (1-7 - sediment samples position), $\mathrm{Mz}$ - mean (phi), $\delta$ - standard deviation (phi), $\mathrm{Ri}$ - roundness index, $\mathrm{Pi}$ - petrographic index.

shows three soft-sediment units, deposited on shallow-lying limestone bedrock. Sedimentary properties of these units are very similar to those of the previously described lower till layer, with the same roundness values and slightly higher amounts of crystalline particles $\left(\mathrm{P}_{\mathrm{i}}\right.$ between 0.60 and 0.66 ). They differ distinctly according to the existence of mollusc shells. The upper layer has the greatest amount of very well preserved Mya truncata (LinNAEUs) of the thick-shelled form, reaching length of $43 \mathrm{~mm}$ and height of $12,5 \mathrm{~mm}$. 


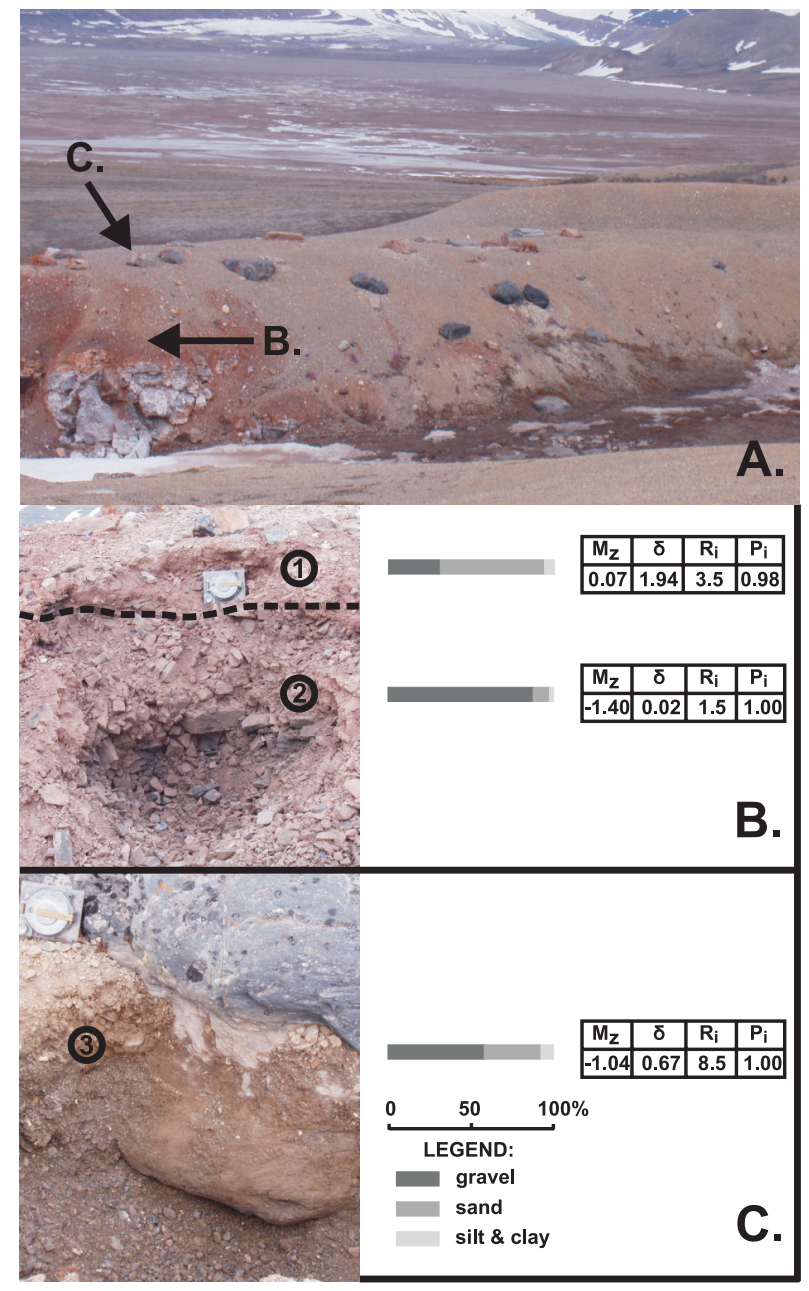

Fig. 3. Study site on the $10 \mathrm{~m}$ a.s.l. raised marine terrace at the western foot of Løvehovden: A. General view of the remnants of the terrace surface with scattered erratic blocks; B. Sediment profile at the terrace edge; C. Sediment profile at the top of the terrace in connection with a partially buried erratic block.

The horizontal edge of the scale compass is $0.1 \mathrm{~m}$ long. 1-3 - sediment samples position. Explanations on Fig. 2.

Among other shell fragments one specimen of Littorina littorea (LinNAEUs) was identified. The middle till layer, dark-brown and compacted, revealed the absence of shell fragments, whereas the separated lowest lens, very similar in macroscopic examination to the above, associated with folded fragments of weathered limestone basement, was supported with small amount of unidentified shell detritus.

The geological-geomorphological setting of the $10 \mathrm{~m}$ a.s.l. terrace at the western foot of Løvehovden (No. 2 on Figs. 1, 3) has been earlier described by Stankowski et al. (1989) as the result of glacier advances in Petuniabukta about 6.5 ky BP, followed by marine transgression and lit- toral accumulation of sandy-gravel deposits of raised marine terraces. The recent morphology of the terrace (Fig. 3a) is the effect of denudation processes that undercut its edges by stream erosion. A shallow sedimentary sequence of anhydrites and limestones is exposed on the slope, topped with a weathered layer of very angular and coarse debris, finally covered with $0.2 \mathrm{~m}$ thick coating of finer, sand-dominated deposits (Fig. 3b). Within the latter unit erratic boulders are rooted. Gravels of the matrix reveal traces of reworking $\left(R_{i}=3.5\right)$ and the existence of singlecrystal rock grains. The flat surface of the terrace, with erratics jutting up to $0.5 \mathrm{~m}$ above, is covered with patches of beach sediments $0.7 \mathrm{~m}$ thick, very well rounded $\left(\mathrm{R}_{\mathrm{i}}=8.5\right)$ and petrographically homogenous, composed of sedimentary rocks with shell fragments (Fig. 3c).

\section{Little Ice Age marginal zones}

The time span after the end of LIA and ice decay of almost all glaciers in Svalbard during the $20^{\text {th }}$ century generated widespread areas of freshly deposited glacial sediments and diversified relief. During this period glaciers around Billefjorden decreased in area between 5.2 and 53.5\% (Rachlewicz et al. 2007). An example of an extensively developed contemporary marginal zone is represented in front of Ebbabreen (Fig. 4) - a glacier nourished from a composite firn area, partly as the eastward tending branch of a bigger Mittag-Lefflerbreen, partly as a valley glacier, descending from about $850 \mathrm{~m}$ a.s.l. to $110 \mathrm{~m}$ a.s.l. at the present snout and to $50 \mathrm{~m}$ a.s.l. at the time of maximum extent during the LIA. The marginal zone was earlier described by Kłysz (1985), Rachlewicz (2003b), Gibas et al. (2005). The total glacier area equals $20.4 \mathrm{~km}^{2}$ and the length reaches $7.6 \mathrm{~km}$. The central part of the valley is cut by a threshold formed by resistant metamorphic rocks, influencing the glacier longitudinal profile. Even in the lowest part, in front of morainic ridges, rock outcrops are visible in the form of scoured surfaces. Valley slopes are dominated by the exaration relief, with roche moutonnés, traces of striae and glacier undercuts up to about $50 \mathrm{~m}$ above the present ice surface. In the upper part of the valley this level is marked with belts of lateral 
moraines, especially on southern slopes, where the glacier turns SW toward its margin. The marginal zone layout has the form of a vast oval with a distinct asymmetry and a three-part construction. The most external segment is composed of the highest ice-cored ridges elevated 20-25 m above the valley bottom filled with outwash series. At the southern margin very intensive processes of transformations of moraines, filled with passive or dead ice, occur through mass movements of till covering ice cores, sinking of englacial caverns and crevasses. In the central part of the marginal zone exist a lowering, adjacent to the rampart that is a remnant of medial moraine, occupied by a set of lakelets, drained through a system of englacial voids to the moraines edge. The medial moraine cover distinctly differ from other parts morphologically, as a undulated belt crossing the central part of the marginal zone, and is composed of homogenous sedimentary rock debris, continuously transferred from the Bastion nunatak in the upper part of glacier basin. In the northern segment of the marginal zone morainic sediments are limited to separate patches deposited on the scoured surface of the rocky threshold about $40 \mathrm{~m}$ high, over which the waterfall carries water from the main subglacial outflow. Accumulation of the main outwash plain at the valley bottom is related to this stream activity.

Sediment distribution was charted in front of most Billefjorden glaciers, and studied also using georesistivity in the Ebbabreen marginal zone (Gibas et al. 2005). Most parts of the front and lateral moraines consist of ice-cored forms covered with various types of glacially-derived debris, accumulated as superimposed basal ice layers, material melted out from detritus-rich shear-planes or transported supraglacially. The maximum thickness of directly accumulated glacial diamicton reaches $2.5 \mathrm{~m}$. Secondary processes of till mass-movement on ice-cores and further processes of ice melt lead to excavation of buried ice surfaces and moistening of material which is sorted and carried away by glacio-fluvial streams (Fig. 5). In proximal parts outwash sediments are very coarse (boulder and cobble fractions) and laid out in narrow channels between morainic deposits. Distally they spread out in the form of broad cones of at least two successive generations, joining together where possible into one
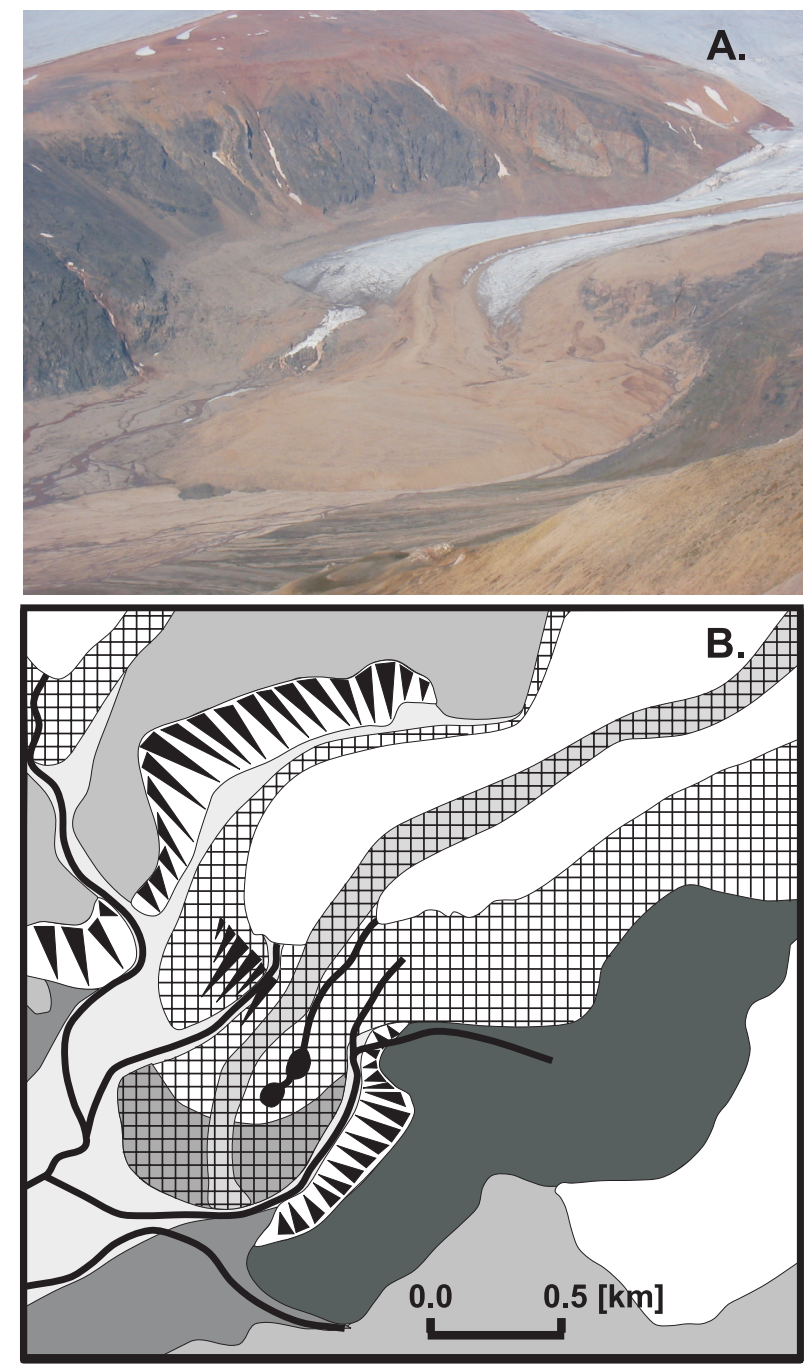

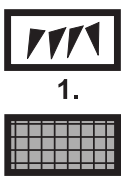

6.

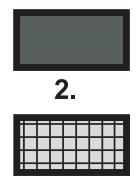

7.

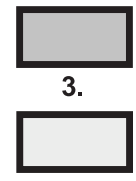

8.

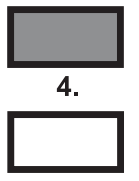

9.

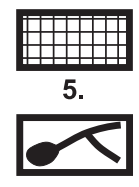

10.
Fig. 4. General view of the Ebba glacier tongue (A.) and geomorphologic sketch of the glacier forefield (B.). 1 - weathering covers; 2 - steep rocky walls; 3 - valley slopes covered with scree; 4 - alluvial fans; 5 - lateral moraines and undisclosed morainic relief; 6 - frontal moraines; 7 - medial moraines; 8 proglacial outwash areas; 9 - glacier ice; 10 - hydrographic network.

extensive outwash plain. Repeated sequences of outwash accumulation reach a thickness of $16 \mathrm{~m}$ in front of Hörbyebreen (Gibas et al. 2005). The outwash surfaces are subjected to intensive wind activity. Mainly during the fall (in September), when the surface is frozen and dry, fine sand and silt fractions are raised and carried relatively long distances, forming clouds that remain airborne for several days, finally mixed and deposited with freshly fallen snow (Fig. 6). Paluszkiewicz 


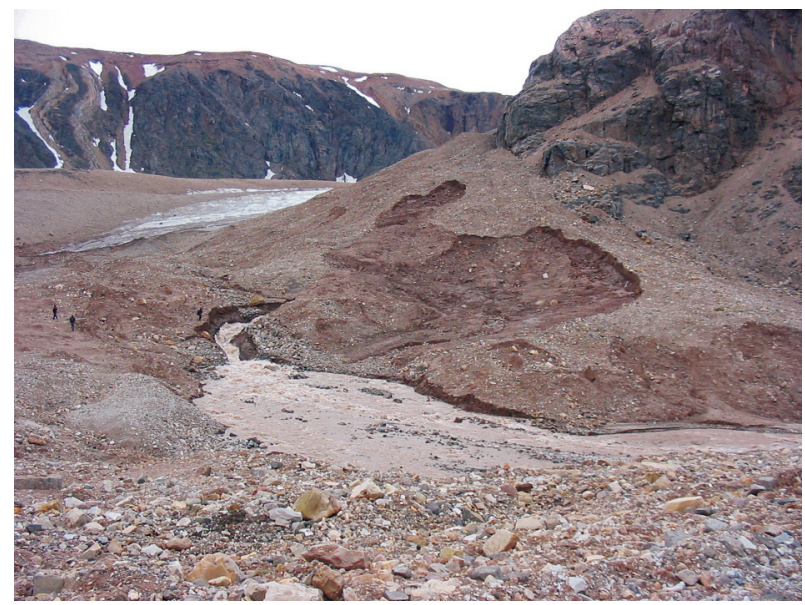

Fig. 5. Till deposited on an ice-cored moraine in the lateral part of Ebba glacier, removed by the processes of sediment flow and an englacial outflow draining the dead-ice zone, initiating outwash accumulation. The picture was taken at the beginning of July 2003.

(2003) estimated the threshold for initiation of aeolian transport in the glaciated valleys of central
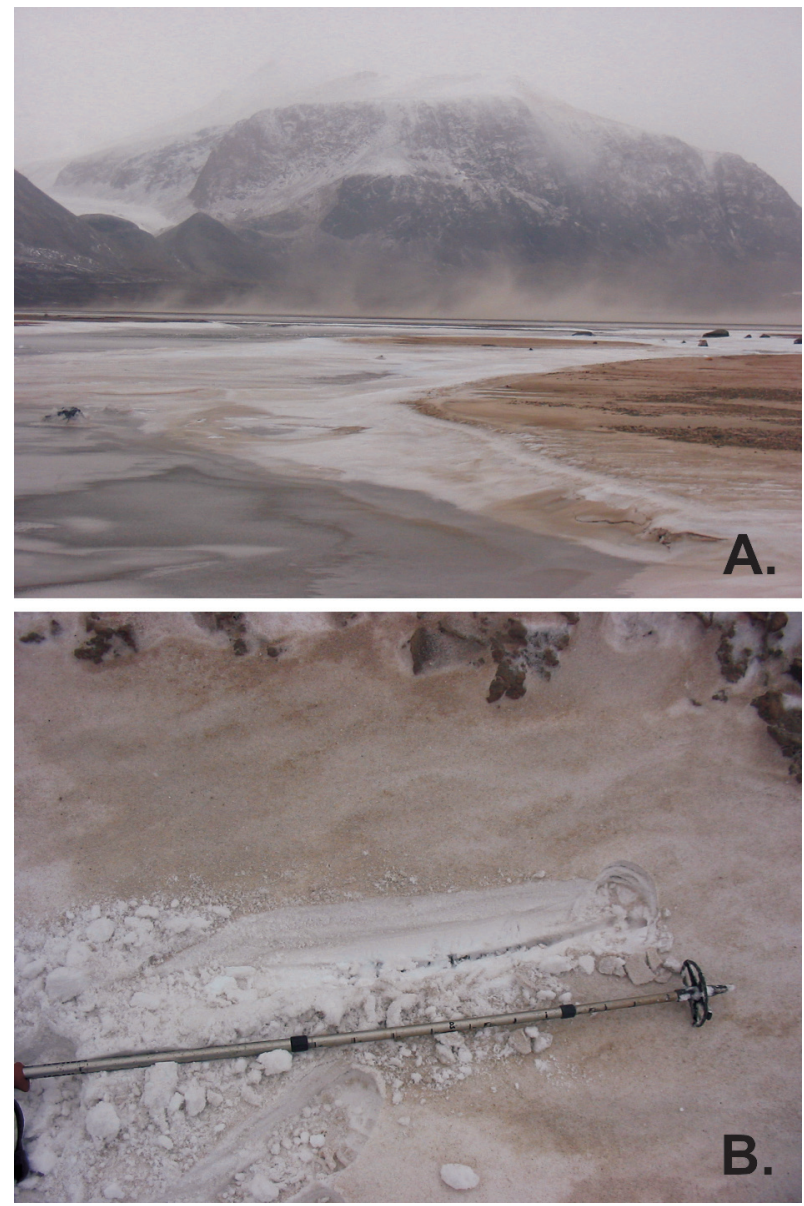

Fig. 6. Aeolian activity on outwash surfaces in the forefield of Hörbye glacier (A.) and its effect in the form of fine sediments mixed with freshly fallen snow (B.).
Spitsbergen as $5 \mathrm{~m} \mathrm{~s}^{-1}$ in summer months, when strong winds are rather rare. My observations in the years 2000-2005 show that after the snow accumulation season niveo-aeolian accumulation ranges between 70 and $115 \mathrm{~g} \mathrm{~m}^{-1}$, while the highest values at the end of the ablation season reach $45 \mathrm{~g} \mathrm{~m}^{-1}$ from one snow-storm event.

\section{Discussion}

The geological setting of the area around Petuniabukta creates anopportunity to identify sources of glacially derived sediments, covering recently created marginal forms and those originating from previous glacial episodes. Both the Weichselian Barents Ice-Sheet and the LIA glacier advance on the eastern and northern coast of the bay crossed outcrops of pre-Devonian metamorphic basement formed from gneiss, schists, quartzites and marbles (Dallmann et al. 2004). The sediments are easily classified, even if the morphologic expression has been destroyed through long-term paraglacial activity, whereas distinguishing between some morphogenetic environments (weathering or other non-glacial ones) is reported as a common problem (Curry \& Ballantyne 1999; Lønne \& Lyså 2005). Primary glacigenic sediments reveal specific textural features, apart from a wide range of grain size distribution classes, i.e. poor and extremely poor sorting, they show some aspects of clast-edge polishing and surface scratching, found at several investigated morainic sites elsewhere in Svalbard (Górka 2003; Karczewski et al. 2003; Piechowiak 2003). Landscape modifications on glacier forefields have been demonstrated as very intensive, leading to significant paraglacial sediment reworking, due to slumping and debris flow on ice-cores filling up the moraines (Ballantyne 2002a). Denudational processes operate in seasonal cycles of dead ice uncovering, melting of the ice core, and sediment wash-out by percolating water or channelized flow on the surface (Rachlewicz 1999). It is found in Svalbard that stabilization of glacial forms, with the preservation of buried ice prolonged over several thousand years (Lønne \& Nemec 2004) under present climatic conditions, is visible within the ramparts, where either the maximum thickness of permafrost active layer is shallower 
than the sediment mantle covering ice-cores, or surface gradients are low (Lønne \& Lyså 2005). Otherwise form stabilization is observed, where such cores have not been detected. That may indicate earlier surge activity of the glacier (Gibas et al. 2005). As was shown by many authors, the most intensive sediment reworking occurs in the initial phase of glacier retreat (e.g. Church \& Ryder 1972; Ballantyne 2002a, b), transported to the coast by the glacio-fluvial system (Laffly \& Mercier 2002), and giving high sedimentation rates of the finest material on the fiord floor (e.g. Koppes \& Hallet 2002, 2006; Zajączkowski et al. 2004). The initial level of sediment susceptibility to the intensity of paraglacial processes has been maintained throughout the recent glacial recession.

The sites where glacial till was found, investigated in front of the maximum extent of LIA moraines, reveal no morphologic evidence of past glacier activity. This is apparent only in the sedimentary record as a continuous glacial diamicton layer, also with specific petrographic and textural features, differentiating them from the results of local slope activity and littoral deposition. Overlying marine material has been dated in this position at about $6 \mathrm{ka} \mathrm{BP}$ (Stankowski et al. 1989). Marine sediments, distinctly different from the underlying glacial deposits, cover the terrace steps or occur in patches separated by erosional incisions. In the upper position, at the level rising to $45 \mathrm{~m}$ a.s.l., the mollusc fauna of Mya truncata (LINNAEUS) of the thick-shelled form is characteristic. Although this species is common throughout the Holocene, the thick-shelled forms are most frequent in deposits older than the Post-Glacial Warm period (Feyling-Hanssen 1955). That fact supported with the absence of other species, like Chlamys islandica (MülLER) and Mytilus edulis (LinNAEUs), found on lower terraces in the valley, superimposed on the same glacigenic level, dates it back at least to the Pleistocene/Holocene transition. The glacially generated forms on valley slopes (possible moraines) described by Kłysz et al. (1989), named Ebbadalen Stage and dated as younger Holocene, found no confirmation in stratigraphic evidences, being rather structural forms or eroded patches of older raised marine terraces (Rachlewicz \& Szczuciński 2003). At this level the millennial time-scale operation of para- glacial processes might completely erase the initial record.

Elsewhere it was observed by the author, that on the top surfaces of surrounding mountain massifs covered by the Weichselian ice-sheet, at t $500 \mathrm{~m}$ a.s.l. and higher, single erratic blocks are planted in a homogenous mass of weathered local material (Fig. 7), which must have been produced after removal of the initial, thin morainic cover susceptible to paraglacial activity. Weathering and mass movement processes on valleys slopes find their expression also in the formation of vast generations of talus cones (Rapp 1960; Kostrzewski \& Zwoliński 2003). Surface levels of glacigenic sediments are intensively reworked by aeolian processes. The dry climate of the island interior (Rachlewicz \& Styszyńska 2007) favours deflation processes and single but intensive niveo-aeolian depositional events, while the total aeolian accumulation is significantly lower than observed in conditions of more maritime high-Arctic climate (Baranowski \& Pękala 1982) that may result from generally lower wind velocities (cf. e.g. Rachlewicz 2003c; Maciejowski \& Michniewski 2007; Marsz \& Styszyńska 2007). In many places features reflecting the unidirectional activity of the strongest winds in this region are visible, expressed by deflation features, eologliptolites, small accumulation forms and thin sandysilt cover patches with ripples (Górska \& Hojan, pers. comm.).

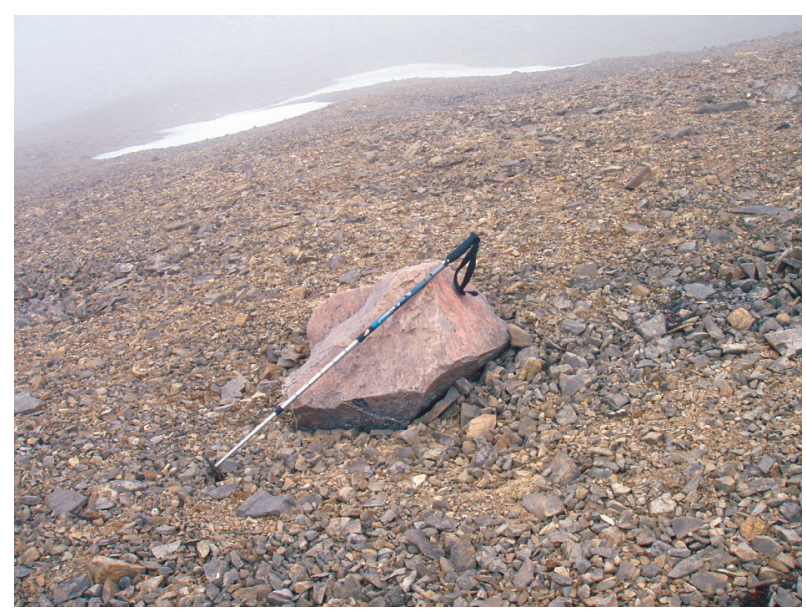

Fig. 7. Metamorphic erratic block partly buried in a weathered limestone cover on the top plateau of Løvehovden. 


\section{Concluding remarks}

The decay of glaciers leaves widespread traces of their activity blurred by paraglacial processes in marginal zones. The record of large extent of late Pleistocene glacial covers on Spitsbergen, their interaction with littoral processes and sea level changes is visible in the characteristics of sediments found in valley floors and coastal cliffs, enriched in exotic petrographic elements and containing partly-buried large erratic blocks. The morphologic expression of this glacial event is preserved neither in the valley floors nor on their slopes. The paleogeographic context of the past glaciations around Billefjorden, contrary to earlier reports (Kłysz et al. 1988, 1989; Stankowski et al. 1989), do not point at their activity during the Holocene. The continuous Weichselian glacigenic layer, descending to the present sea level, is covered with shelves of raised marine terraces of younger and younger age. Recession from the LIA maximum some 100 years ago has left the most significant set of forms in the valleys, originating from direct glacial accumulation and glaciofluvial activity. Freshly deposited and unstable sediments settled on ice are the most susceptible for further modifications by mass movements, providing the main mass delivered to the streams and forming areas of proglacial accumulation. Further paraglacial activity involves aeolian processes supported with snow cover ablation; washing out sediments in conditions of shallow level of permafrost table; and general water outflow to intensively prograding sea coasts. As the denudation rates in glacier-marginal zones are high, the morphologic changes are visible especially where sediment cover is thinner than the depth of thaw over ice-cores.

\section{Acknowledgements}

Field studies in the years 2001-2003, 2005, 2008 and data elaboration were supported by grants no. 6 PO4E 041 21, PBZ-KBN 108/P04/ 2004 and N306-05832/3651 from the Polish Ministry of Scientific Research. The author wish to thank members of A. Mickiewicz University in Poznan Svalbard expeditions for field assistance, particularly dr. Witold Szczuciński for his reliable help and long discussions. Thanks are due to Professor Ian S. Evans and Professor Piotr Migoń for thorough reviews that improved the manuscript.

\section{References}

Armstrong R. L., Brodzik M. J., Durgerov M., Maslanik J. A., Serreze M., Stroeve J. \& Zhang T., 2002. Report Glaciological Data. National Snow and Ice Data Center, World Data Center for Glaciology, Boulder 30: 18-24.

Ballantyne C. K., 2002a. Paraglacial geomorphology. Quaternary Science Reviews 21: 1935-2017. DOI: 10.1016/S02773791(02)00005-7

Ballantyne C. K., 2002b. A general model of paraglacial landscape response. The Holocene 12(3): 371-376. DOI: 10.1191/0959683602hl553fa

BaranowsKi S. \& PęKALA K., 1982. Nival-aeolian processes in the tundra areas and the nunatak zone of the Hans and Werenskiold Glacier (SW Spitsbergen), Acta Universitatis Wratislaviensis 525: 11-27.

BLOTT S., 2000. GRADISTAT version 4.0 - a grain size distribution and statistics package for the analysis of unconsolidated sediments by sieving or laser granulometer, http://www. gl.rhul.ac.uk

Boulton G. S., 1979. Glacial history of the Spitsbergen archipelago and the problem of a Barents Shelf ice sheet. Boreas 8: 31-57.

Church M. \& RYder J. M., 1972. Paraglacial sedimentation: a consideration of fluvial processes conditioned by glaciation. Bulletin of Geological Society of America 83: 30593072.

Curry A. M. \& Ballantyne C. K., 1999. Paraglacial modification of glacigenic sediment. Geografiska Annaler $81 \mathrm{~A}(3)$ : 409-419. DOI: $10.1111 / 1468-0459.00070$

Dallmann W. K., Pipejohn K. \& Blomeier D., 2004. Geological map of Billefjorden, Central Spitsbergen, Svalbard with geological excursion guide 1:50,000. Norsk Polarinstitutt Tematkart 36.

Dyurgerov M.\& McCabe G. J., 2006. Associations between accelerated glacier mass wastage and increased summer temperature in coastal regions. Arctic Antarctic and Alpine Research 38(2): 190-197.

Evenson E. B. \& Clinch J. M., 1987. Debris transport mechanisms at active alpine glacier margins: Alaskan case studies. In: R. Kujansuu \& M. Saarnisto (eds.): INQUA Till Symposium, Finland 1985. Geological Survey of Finland, Special Papers 3: 111-136.

FeYling-Hanssen R.W., 1955. Stratigraphy of the marine latePleistocene of Billefjorden, Vestspitsbergen, Norsk Polarinstitutt Skrifter 107: 186 p.

FolK R. L. \& WARD W. C., 1957. Brazos River bar: a study in the significance of grain size parameters. Journal of Sedimentary Petrology 27: 3-26.

Gibas J., Rachlewicz G. \& SzczucińsKi W., 2005. Application of DC resistivity soundings and geomorphological surveys in studies of modern Arctic glacier marginal zones, Petuniabukta, Spitsbergen. Polish Polar Research 26(4): 239-258.

GóRKA T., 2003. Transport fluvioglacjalny i wyksztatcenie osadów sandrowych $w$ dolinie lodowca Ragnar, Spitsbergen środkowy - sezon letni 2002, Manuscript of MSc thesis, Inst. Geology, A. Mickiewicz University in Poznań: 58 p. 
KarczewsKi A. \& RYgielski W., 1989. The profile of glacial deposits in Hörbyedalen and an attempt at their stratigraphy, central Spitsbergen. Polish Polar Research 10(3): 401-409.

Karczewski A., Rachlewicz G. \& SzcZucińsKi W., 2003. Sediment textures in contemporary glacigenic environments with examples from Hansbreen, southern Spitsbergen. Geologos 6: 111-131.

KŁYsz P., 1985. Glacial forms and deposits of Ebba Glacier and its foreland (Petuniabukta region, Spitsbergen). Polish Polar Research 6; 283-299.

KŁYsz P., Lindner L., MaKowsKa A., Marks L. \& WYSOKIŃSKI L., 1988. Late Quaternary glacial episodes and sea level changes in the northeastern Billefjorden region, Central Spitsbergen. Acta Geologica Polonica 38(1-4): 107-123.

KEYsz P., Lindner L., MARKS L. \& WysOKińSKi L., 1989. Late Pleistocene and Holocene relief remodelling in the Ebbadalen-Nordenskjöldbreen region in Olav V Land, central Spitsbergen. Polish Polar Research 10(3): 277-301.

Koppes M. N. \& Hallet B., 2002. Influence of rapid glacial retreat on the rate of erosion by tidewater glaciers. Geology 30(1): 47-50. DOI: 10.1130/0091-7613(2002)030<0047

Koppes M. N. \& Hallet B. , 2006. Erosion rates during rapid deglaciation in Icy Bay, Alaska. Journal of Geophysical Research 111, F02023. DOI: 10.1029/2005JF000349.

KostrZewsKi A. \& ZwolińsKi Z., 2003. Środowisko sedymentacyjne stożków piargowych. Materiały Warsztatów Spitsbergeńskich SGP: 49-52.

LAFFly D. \& Mercier D., 2002. Global change and paraglacial morphodynamic modification in Svalbard. International Journal of Remote Sensing 23(21): 4743-4760. DOI: 10.1080/01431160110113872

Lavrushin J. A., 1969. Tchetvertnye osadki Spitsbergena. Poiski VII Kongresa INQUA, Nauka, Moskva. 1777 p.

LøNNE I. \& LYSÅ A., 2005. Deglaciation dynamics following the Little Ice Age on Svalbard: Implications for shaping of landscapes at high latitudes. Geomorphology 72: 300319. DOI: 10.1016/j.geomorph.2005.06.003

LønNe I. \& NEMEC W., 2004. High-arctic fan delta recording deglaciation and environment disequilibrium. Sedimentology 51: 552-589. DOI: 10.1111/j.1365-3091.2004.00636.x

MACIEJOWSKI W. \& MichNIEWSKI A., 2007. Variations in weather on East and West coasts of South Spitsbergen, Svalbard. Polish Polar Research 28(2), 123-136.

Mangerud J., Dokken T., Hebbeln D., Heggen B., Ingólfssson O., Landvik J. O., Mejdahl V., Svendsen J. I. \& Vorren T. O., 1998. Fluctuations of the Svalbard-Barents sea ice sheet during the last 150000 years. Quaternary Sciciece Review 17: 11-42.

Mangerud J. \& Svendsen J. I., 1992. The last interglacial-glacial period on Spitsbergen, Svalbard. Quaternary Science Reviews 11: 633-664.

Marsz A. A. \& Styszyńska A., 2007: Klimat rejonu Polskiej Stacji Polarnej w Hornsundzie - stan, zmiany i ich przyczyny. Wydawnictwo Akademii Morskiej w Gdyni: 376pp.

Oerlemans J., 2005. Extracting a climate signal from 169 glacier records. Science 308: 675-677. DOI: $10.1126 /$ science. 1107046

PALUSZKIEWICZ R., 2003. Zróżnicowanie natężenia transportu eolicznego $\mathrm{w}$ warunkach polarnych jako efekt zmien- ności czynników meteorologicznych na przykładzie doliny Ebby (Petuniabukta, Billefjorden, Spitsbergen Środkowy). Proceedings of the $29^{\text {th }}$ International Polar Symposium, Kraków: 235-238.

PIECHOWIAK M., 2003. Transport fluvioglacjalny $i$ wyksztatcenie osadów sandrowych doliny lodowca Hörbye, Spitsbergen środkowy - sezon letni 2002. Manuscript of MSc thesis, Inst. Geology, A. Mickiewicz University in Poznań: 66 p.

POWERS M. C., 1953: A new roundness scale for sedimentary particles. Journal of Sedimentary Petrology 23: 117-119.

RACHLEWICZ G., 1999. Glacial relief and deposits of the western coast of Admiralty Bay, King George Island, South Shetlands. Polish Polar Research 20(2): 89-130.

RACHLEWICZ G., 2003a. Uwarunkowania środowiskowe obiegu wody w systemie lodowca Hörbye (środkowy Spitsbergen). In: A. Kostrzewski \& J. Szpikowski (eds.): Funkcjonowanie Geoekosystemów Zlewni Rzecznych, tom III, Bogucki Wydawnictwo Naukowe: 351-365.

RACHLEWICZ G., 2003b. Charakterystyka i procesy glacjalne lodowca Ebba. Materiaty Warsztatów Spitsbergeńskich SGP: 43-46.

RACHLEWICZ G., 2003c: Warunki meteorologiczne w Zatoce Petunia (Spitsbergen Środkowy), w sezonach letnich 2000-2001. Problemy Klimatologii Polarnej 13: 127-138.

Rachlewicz G. \& StYszyŃSKa A., 2007. Porównanie przebiegu temperatury powietrza w Petuniabukta i SvalbardLufthavn (Isfjord, West Spitsbergen) w latach 2001-2003. Problemy Klimatologii Polarnej 17: 121-134.

RACHLEWICZ G. \& SzCZUCIŃSKI W., 2003. Czwartorzędowe podniesione osady morskie centralnego Spitsbergenu - nowe dane. Materiaty IV Sympozjum Geneza, Litologia i Stratygrafia Utworów Czwartorzędowych, Poznań: 72.

Rachlewicz G., Szczuciński W. \& Ewertowski M., 2007. Post - "Little Ice Age" retreat rates of glaciers around Billefjorden in central Spitsbergen, Svalbard. Polish Polar Research 28(3): 159-186.

RAPP A., 1960. Talus slopes and mountain walls at Tempelfjorden, Spitsbergen. Norsk Polarinstitutt Skrifter 119: 96 p.

RYDER J. M., 1971. The stratigraphy and morphology of paraglacial alluvial fans in south-central British Columbia. Canadian Journal of Earth Science 8: 279-298.

SLAYMAKer O., 2009.Proglacial, periglacial or paraglacial?. Geological Society, London, Special Publications 320: 71-84. DOI: $10.1144 /$ SP320.6

Snyder J. A., Werner A.\& Miller G. H., 2000. Holocene cirque glacier activity in western Spitsbergen, Svalbard: sediment records from proglacial Linnévatnet. The Holocene 10(5): 555-563. DOI: 0959-6836(00)HL417RP

StanKOWSKI W., KasprZaK L., KostrZeWSKi A. \& RYgIelsKi W., 1989. An outline of morphogenesis of the region between Hörbyedalen and Ebbadalen, Petuniabukta, Billefjorden, central Spitsbergen. Polish Polar Research 10(3): 267-276.

Svendsen J. I. \& Mangerud J., 1992. Paleoclimatic inferences from glacial fluctuations on Svalbard during the last 20000 years. Climate Dynamics 6: 213-220.

ZAJĄCZKOWSKI M., SZCZUCIŃSKI W. \& BOJANOWSKI R., 2004. Recent sediment accumulation rates in Adventfjorden, Svalbard. Oceanologia 46: 217-231. 